Bulletin of the Natural History Museum, 2015, 7: 101-117.

Received 25 Feb 2015; Accepted 30 Dec 2015.

doi:10.5937/bnhmb1508101D

UDC: $582.661 .21(497.11)$

Original scientific paper

\title{
DISTRIBUTION AND COMMUNITIES OF SUAEDA PANNONICA IN SERBIA
}

\author{
DANIEL DítĚ ${ }^{1}$, RANKo Perić ${ }^{2}$, PAVOl Eliáš JUN. ${ }^{3}$ ZUZANA MELEČKOVÁ ${ }^{1}$ \\ ${ }^{1}$ Institute of Botany, Slovak Academy of Sciences, Dúbravská cesta 9, 84523 \\ Bratislava, Slovakia, e-mails: daniel.dite@savba.sk, zuzana.meleckova@savba.sk \\ ${ }^{2}$ Institute for Nature Conservation of Vojvodina province, Radnička 20a, 21000 \\ Novi Sad, Serbia, e-mail: ranko.peric@pzzp.rs \\ ${ }^{3}$ Department of Botany, Slovak University of Agriculture, Tr. A. Hlinku 2, 94976 \\ Nitra, Slovakia, e-mail: pavol.elias.jun@gmail.com
}

In this article are presented data referring to the distribution and phytocoenology of Suaeda pannonica in Serbia. Between the years 2009 and 2013 we confirmed this species on four localities from the total of about 10 its known sites. It was found on the banks and bottoms of salt lakes Medura, Slano Kopovo, Rusanda and Okanj in Bačka and Banat. We also recorded 25 phytosociological relevés with S. pannonica. Besides community Suaedetum pannonicae the species occurs in other associations within the class Thero-Suaedetea, alliance Salicornion prostratae: Salicornietum prostratae, Crypsido-Suaedetum maritimae and in a separate cluster, i. e. combination of species Suaeda pannonica - Chenopodium chenopodioides which syntaxonomical character is unresolved. In comparison with previously published data, recent situation indicates gradual vegetation changes and habitat loss at all remaining localities of S. pannonica in Serbia.

Key words: endangered species, halophytes, Suaeda, saline lakes. 


\section{INTRODUCTION}

Denuded banks and bottoms of inland salt lakes are extremely peculiar habitats with sub-continental, semi-desert character. Their vegetation is represented with open to moderately closed succulent therophyte stands exhibiting low species diversity. Communities of the Thero-Suaedetea class occupy places which show distinctly large fluctuations of moisture with pronounced semidry season during the year. The vegetation is composed only of obligate halophytes (cf. Borhidi 2003). These halophytes include also the representatives of the genus Suaeda.

The genus Suaeda Forssk. ex J.F. Gmel. (Chenopodiaceae s.str.; Amaranthaceae sensu APG) has a large geographical range and belongs to the critical taxa of the European flora. In spite of the high number of published studies (e.g. Bassett \& Crompton 1978, Akhani et al. 1997, Lomonosova et al. 2005, Kapralov et al. 2006) the determination of the subgeneric taxa is not unified so far and their exact number is not even known. In Europe 30 (31) taxa are reported majority of which are occurring on strictly coastal saline habitats (Uotila 2011). Much less number of species are characteristic for the inland saline habitats. With the exception of Ukraine and European part of Russia the largest distribution range of inland saline vegetation in Europe is inside the Pannonian Basin, with three documented representatives of the genus Suaeda: S. pannonica Beck), $S$. prostrata Pallas and S. salinaria (Schur) Simk. (Mile \& Walter 2003). Their taxonomy, nomenclature, distribution, as well as their connection with coastal S. maritima (L.) Dumort., were intricate and controversial so far (Freitag et al. 1996, Mile \& Walter 2003, Fischer \& Kästner 2011).

From the Serbian part of the Pannonian Basin (Vojvodina) are known two species, S. prostrata (S. maritima auct. serb., p.p., non (L.) Dumort.) and S. pannonica (cf. Slavnić 1939, 1972, Sturc 1973, Knežević \& Boža 1987). The records of $S$. prostrata in Vojvodina, instead of coastal $S$. maritima, were sporadically published on rare occasions (e.g. Guelmino 1968, Gajić 1986, Boža \& Vasić 1986, Budak 1998; ) and confirmed by Freitag et al. (1996).

Suaeda prostrata Pallas [syn.: S. maritima subsp. prostrata (Pall.) Soó; $S$. maritima sensu auct. serb., p.p.] is a species with Eurasian but somewhat uncertain distribution range. In the Pannonian Basin, it occurs in E. Austria (around lake Neusiedl), in Hungary and Serbia. There are several opinions about its rather large areal across Ukraine, Russia, Transcaucasia and Siberia (Freitag \& Lomonosova 1996, Zhu Gelin et al. 2003, Fischer \& Kästner 2011). On the NW border of its distribution range (Czech Republic, South Morava region) it has disappeared (Šumberová 2007), as well as from the northern part of Hungary (Schmidt 2007). 
Suaeda pannonica Beck [syn. Schoberia pannonica Beck; Suaeda maritima subsp. pannonica (Beck) Soó ex P.W. Ball] is considered as a Pannonian endemic (Tatár 1939). It is reported around lake Neusiedl in E. Austria (Mucina 1993, Fischer \& Kästner 2011), from Hungary (Boros 1959, Borhidi 2003, Király 2009) and N. Serbia. The distribution range extends also to the Transylvania in W. Romania (Ciobanu et al. 2004). In the northern part of the Pannonian Basin, it was not recorded in Slovakia (Marhold \& Hindák 1998), while in the Czech Republic was erroneously reported (Šumberová 2007). Data from Ukraine and SE Russia need to be revised (Mile \& Walter 2003). In case of their confirmation S. pannonica would rather be a Pannonian sub-endemic or Pontic-Pannonian endemic (Fischer \& Kästner 2011).

Both S. prostrata and S. pannonica grow in periodical wet habitats with high soil salinity, in most cases on dried banks and bottoms of shallow salt pans. S. pannonica creates mono-dominant stands of the association Suaedetum pannonicae representing vegetation of the class Thero-Suaedetea, alliance Salicornion prostratae, but it also occurs in other communities within the alliance and it sporadically occurs within the class Crypsidetea aculeatae as well (Wendelberger 1943, 1950, Slavnić 1948, Borhidi 2003). $S$. prostrata has a little different coenological affinities, it does not create mono-dominant stands as $S$. pannonica, it occurs rather in the alliance Puccinellion limosae within the class Festuco-Puccinellietea.

The objective of this contribution is to complete the historical and recent distribution of $S$. pannonica in Serbia and to characterize the recent status of its plant communities and habitats.

\section{MATERIAL AND METHODS}

Analysis of phytosociological and ecological affinities of S. pannonica were based on traditional phytosociological approach. During the vegetation seasons from 2009 to 2013, phytosociological relevés (25) were sampled following the Zürrich-Montpellier approach with adapted ninegrade Braun-Blanquet scale (Barkmann et al. 1964). All relevés were stored in the TURBOVEG database (Hennekens \& Schaminée 2001) and exported to the JUICE program (Tichý 2002).

The nomenclature of vascular plants is given according to Tutin et al. (1968-1980, 1993), nomenclature of genus Suaeda mostly follows Freitag et al. (1996), but it was corrected after reviewing the original descriptions. Author citations has complied with the Code (McNeil et al. 2012: Rec. $46 \mathrm{~A}$, Note 1). Nomenclature of the syntaxa is based on work of Molnár \& Borhidi (2003). The names of communities which are not mentioned in that work are presented with the name(s) of author(s) of the description. 
Herbarium abbreviations are given according to Thiers (2014) with the exception of the herbarium of the Institute for Nature Conservation of Vojvodina province in Novi Sad (PZZP).

Distribution of the species in Serbia is given on a map with $10 \times 10 \mathrm{~km}$ MGRS grid system (Lampinen 2001).

\section{RESULTS}

\section{Historical and recent distribution of Suaeda pannonica in Serbia}

In total, $S$. pannonica is present (historically as well) only in the northern part of the country. It was clearly reported from nine localities distributed within eight MGRS squares: five squares in the Bačka region (localities: Subotica, Krvavo lake, Slano lake, Riđica, Gornji Breg near Senta and Novi Sad) and three squares in the Banat region (localities: Slano Kopovo near Novi Bečej, Rusanda near Melenci and Okanj between Melenci and Elemir), while the data from the vicinity of Sombor (two squares, localities: Gakovo and Stanišić remain questionable due to the insufficiency of data given by its author) (Fig. 1, Appendix).

Based on our field investigations of saline habitats in Vojvodina, we have documented this species on four localities on dried bottoms of saline lakes i. e. from lakes Medura (near Riđica), Rusanda, Okanj and Slano Kopovo.

\section{RIĐICA, LAKE MEDURA}

S. pannonica was observed mostly on the eastern and southern banks of the periodically dried saline lake Medura. The species occurred with low cover values and it was accompanied by Chenopodium chenopodioides, Crypsis aculeata, Cyperus pannonicus and Puccinellia distans agg.

\section{NOVI BeČEJ, SLANO KoPOVO}

This is the largest known stand of $S$. pannonica in Serbia (cca. 1.32 $\mathrm{km}^{2}$ ) occupying the large, shallow periodically dried saline lakebed. In years of low precipitation and hot dry summers (e.g. 2009) the monocoenoses of S. pannonica were distributed across the whole desiccated lakebed with average cover values of $15-20 \%$. In 2012 we did not record any individual at all, with some other halophytes such Crypsis aculeata and Salicornia europaea s.l. recorded only on the northern lake ends.

\section{MELENCI, RUSANDA}

The lake is located near the western side of the village Melenci and consisting of two interconnected portions: bigger called Velika Rusanda and smaller known as Mala Rusanda. Velika Rusanda is with area of $1.5 \mathrm{~km}^{2}$ 
and has irregular drying periods. Populations of $S$. pannonica were concentrated only on the banks and along the shallow littoral zone in the western part of the lake. The lakebed itself remained vegetation free even after the water retreat. The monocoenoses of $S$. pannonica were accompanied with Puccinellia distans agg., Phragmites australis and sporadically with Crypsis aculeata.

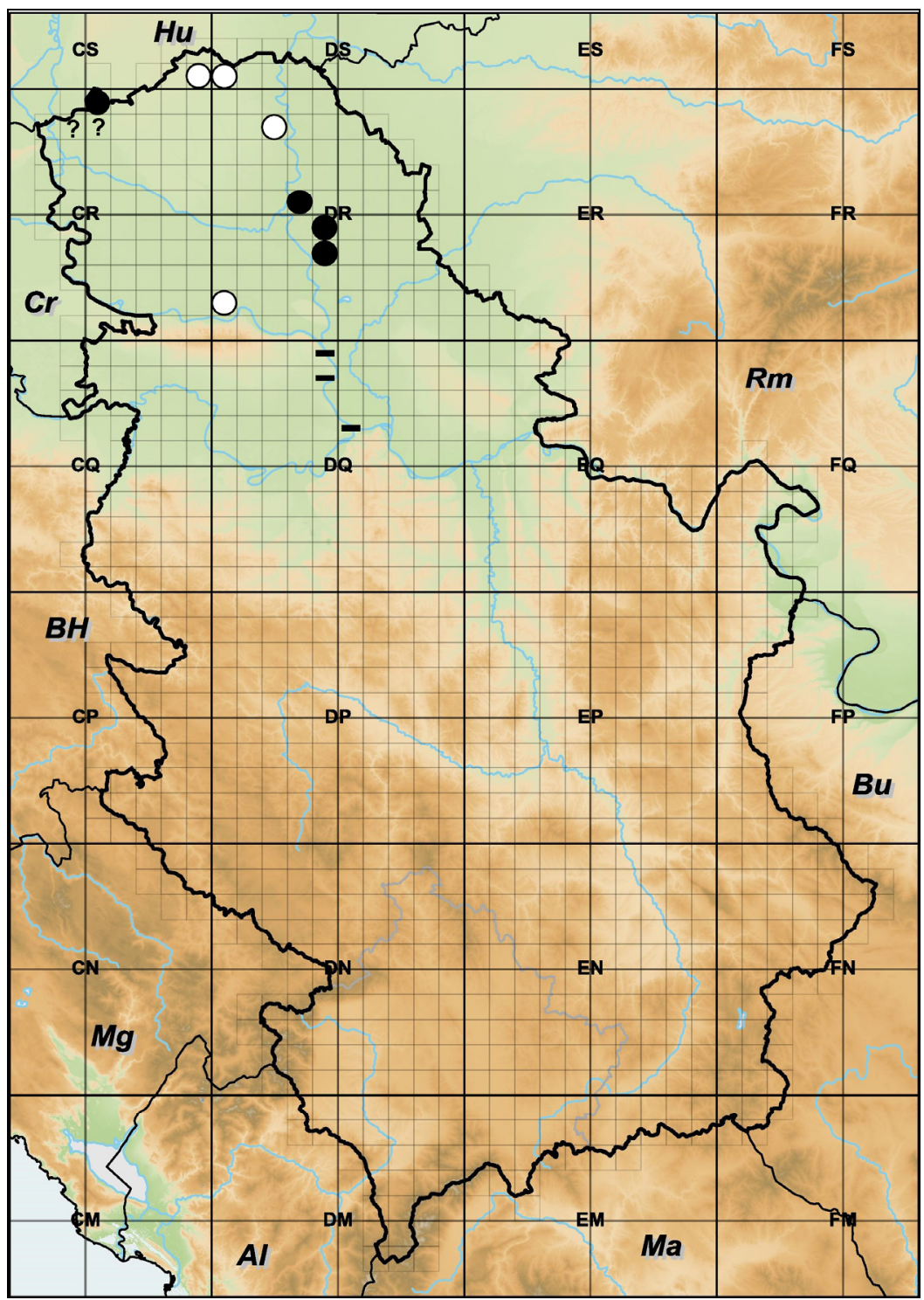

Fig. 1. - Distribution of Suaeda pannonica in Serbia: • - recently documented locatilities (after the year 2000), o- historical records (from 1914 to 1998), "?”- questionable data, “-" - erroneous data. 
Mala Rusanda has the area of only $0.25 \mathrm{~km}^{2}$ and where the stands of $S$. pannonica are also restricted to the banks and to the shallow littoral zone. $S$. pannonica was accompanied with $S$. prostrata and other species (e.g. Atriplex littoralis, Chenopodium chenopodioides, Ch. glaucum).

\section{ELEMIR, OKANJ}

The southernmost occurrence of S. pannonica in studied area is on periodically dried saline lake Okanj. Compared to the previous localities, the population is poor, not creating continuous stands. S. pannonica were represented with solitary individuals or small clumps among the vegetation dominated by Chenopodium glaucum and Ch. chenopodioides, sporadically accompanied with Crypsis schoenoides and Crypsis aculeata.

\section{Syntaxonomic preferences of $S$. pannonica in Serbia}

The analyzed dataset of 25 own relevés with Suaeda pannonica was divided into four clusters. Cluster 1 comprises vegetation from the northern edge of the dried lake Slano Kopovo (Tab. 1, rel. no. 1-7). These stands are moderately closed, cover values varying between 20 to $40(-65) \%$. Species richness is low, however, this cluster contains most species among the whole dataset (in average four species per relevé). Salicornia europaea s.l. occurs constantly with average cover of $15 \%$ and $S$. pannonica only $5 \%$, maximally $15 \%$. These species are accompanied by Puccinellia distans agg. (average cover 5-15\%, in two cases more than 50\%) and with low cover values of Spergularia marina, S. media and Aster tripolium subsp. pannonicus. We classified this vegetation into the class Thero-Suaedetea, alliance Salicornion prostratae, association Salicornietum prostratae.

Cluster 2 (Tab. 1., rel. no. 9-11) contains relevés also from Slano Kopovo with two species - Crypsis aculeata and S. pannonica, each with identical abundance, while total cover is around 35\%. The vegetation represents a transition between associations Crypsietum aculeatae and Suaedetum pannonicae. This type is defined as a separate association called Crypsido-Suaedetum maritimae.

In Cluster 3 (Tab. 1., rel. no. 12-16) there are relevés from Riđica and Melenci (Mala Rusanda). Together with S. pannonica, which had high cover value (around 50\%) Chenopodium chenopodioides is also dominant with 5-(15-25) \% cover. Concerning the high cover of S. pannonica we can consider these stands as association Suaedetum pannonicae.

Relevés in Cluster 4 (Tab. 1, rel. no. 17-25) were collected from Slano Kopovo and Rusanda lakes and represent ass. Suaedetum pannonicae as well with other accompanying species. Dense monocoenoses of $S$. pannonica with cover from 25 to $90 \%$ were sporadically recorded with 
Puccinellia distans agg., Phragmites australis and in a single case Camphorosma annua (Tab. 1., rel. no. 20).

Table 1. - Analytic table with Suaeda pannonica relevés recorded in northern Serbia.

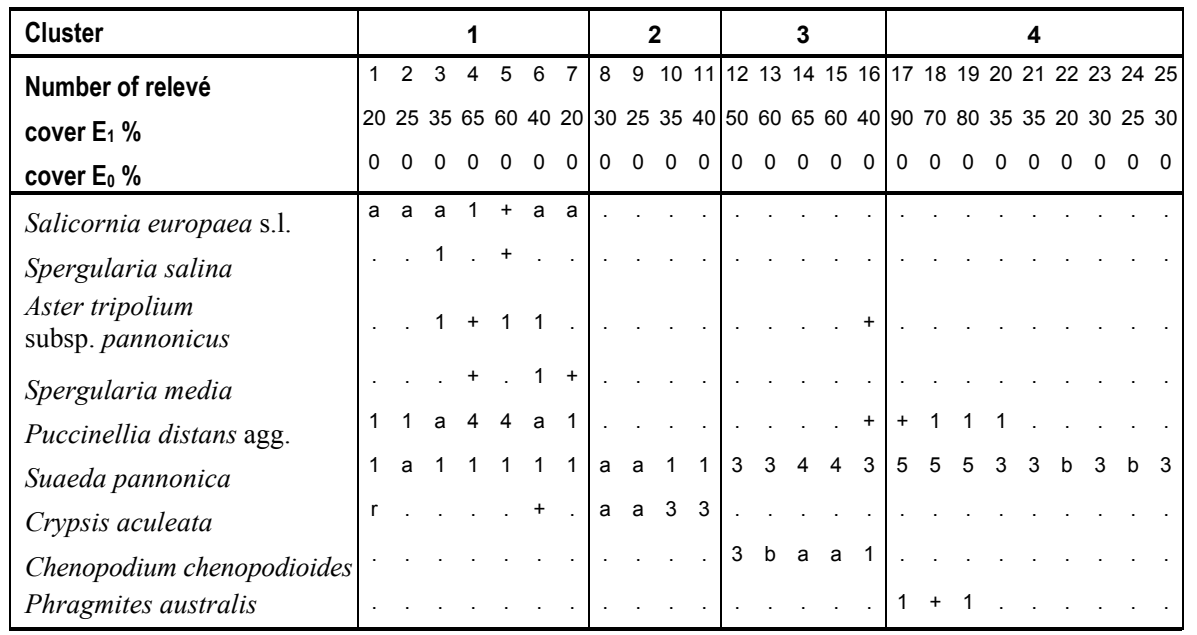

Species recorded in single relevé only: Atriplex littoralis $+(16)$; Camphorosma annua + (20); Polygonum arenastrum + (4); Suaeda prostrata 2a (16).

\section{Locations of relevés}

1-7. Slano Kopovo, bare bottom of lake, $72 \mathrm{~m}$ a. s. $1 ., 16 \mathrm{~m}^{2}$, 13-Aug-2009.

8-11. Slano Kopovo, bare bottom of lake, northern part, $72 \mathrm{~m}$ a. s. $1 ., 16 \mathrm{~m}^{2}$, 13-Aug-2009.

12-15. Riđica, bare bottom of lake, 93 m a. s. 1., 16 m², 30-Aug-2012.

16. Melenci, Mala Rusanda lake, southern part, $72 \mathrm{~m}$ a. s. $1 ., 16 \mathrm{~m}^{2}$, 31-Aug-2012.

17-20. Melenci, Rusanda lake, northern part, $72 \mathrm{~m}$ a. s. $1 ., 16 \mathrm{~m}^{2}$, 12-Aug-2009.

21-23. Slano Kopovo, bare bottom of lake, $72 \mathrm{~m}$ a. s. $1 ., 16 \mathrm{~m}^{2}$, 13-Aug-2009.

24-25. Melenci, Rusanda lake, northern part, 72 m a. s. $1 ., 16$ m², 12-Aug-2009.

\section{DISCUSSION}

During our study we visited four known localities of S. pannonica in Serbia and confirmed its presence in one locality in Bačka (Riđica) and three in Banat (Okanj, Rusanda, Slano Kopovo), while the historical records from the other known localities were not checked (see Appendix). Concerning the population trends on these historical stands evaluated by Boža (1999) they were pre-considered as most likely destroyed. Accor- 
dingly, despite the fact that $S$. pannonica has disappeared from other localities in vicinity of Sombor (Stanišić and Gakovo) (Đakić et al. 2012, Boža 1999), we confirmed $S$. pannonica in this region after a long time near Riđica. Relatively large populations of $S$. pannonica were observed there together with extremely rare Cyperus pannonicus (Dítě et al. 2013).

Beside Bačka and Banat, data relating to the presence of $S$. pannonica in Srem region (Obradović 1966: 134, 1987: 107) are erroneous. They are based on the misinterpretation of the Kitaibel records of Salsola prostrata (= Bassia prostrata (L.) A.J. Scott) (Gombocz 1945: 514-515, 517) which are later cited or transcribed by various authors under the names Salsola fruticosa (Kanitz 1863: 71), Schoberia fruticosa (Schlosser \&Vukotinović 1869: 965), Suaeda pannonica (Obradović 1.c.) and eventually indicated under the name Suaeda vera Forssk. ex J.F. Gmel. by Jalas \& Suominen (1980. 72) and Nikolić (2005: 525-526) as "questionable" for Danube lowland.

Slavnić (1948) published plant communities with Suaeda species first for Serbia under the name Suaedetum maritimae hungaricum Soó 1927. Together with S. prostrata ("S. maritima"), which has cover from 25 to $40 \%$ in his relevés, he recorded with a low cover Crypsis aculeata and Puccinellia distans agg. as well. He described this association in the northern part of the Bačka region (Senta, Subotica, Martonoš) and fragmentary from the rest of the Bačka and Banat, but without any data about $S$. pannonica. In his previous paper however, he published data about presence of S. pannonica in the vicinity of Senta (Slavnić 1939).

Firstly, the community Suaedetum pannonicae has been mentioned for Serbia by Parabućski et al. (1986) as a synonym of Suaedetum maritimae hungaricum Soó with two subassociations: bolboschoenetosum maritimae Čapaković 84 and asteretosum pannonicae Capaković 84. The author of these subassociations, Jelica Capaković, never published them and they were only subsequently cited from her manuscript by Parabućski et al. (1986) without any relevé or further explanation. Therefore, these two subassociations are described invalidly (see Weber et al. 2000: Art. 2).

Exact data about community with $S$. pannonica in Serbia under the correct name Suaedetum pannonicae (Soó 1927) Wendelbg. 1943 were published for the first time by Knežević \& Boža (1987) from the Rusanda lake. The community was documented by five relevés. S. pannonica reached constancy level of $\mathrm{V}$., cover of 25-75\% and it was accompanied with low cover of Aster tripolium subsp. pannonicus, Atriplex littoralis and Puccinellia distans agg. Accessorial species were Camphorosma annua and Polygonum aviculare. In contrast to our recent findings (Tab. 1, rel. no. 24, $25)$, dense populations and monocoenoses of $S$. pannonica were not recorded. 
Except the association Suaedetum pannonicae Knežević and Boža (1990) mentioned also vegetation with $S$. prostrata (as S. maritima) from Rusanda lake under the name Suaedetum maritimae hungaricum Soó 33 (ex Wendelbg. 43, 50). From the floristical point of view, with the exception of dominants the stands are almost identical with the association Suaedetum pannonicae, with sporadic occurrence of Salsola soda, Phragmites australis, Bolboschoenus maritimus s.1. and Crypsis aculeata. According to several authors (Knežević \& Boža 1987, Mile \& Walter 2003) the ecological differences between these communities are clearly pronounced: Suaedetum pannonicae occupies habitats with longer inundation time and slower drying process, while Suaedetum maritimae is more typical where inundation is shorter and the habitats dries out quickly. There is no relevé where both species grow together. We recorded $S$. prostrata on the southern part of Mala Rusanda lake very rarely in 2012 where it occurred together with S. pannonica (Tab. 1, rel. no. 16). Therefore, we can agree with Vučković (1986) that proper name of Suaedetum maritimae hungaricum should be Suaedetum maritimae pannonicum because there are no real ecological, floristic and phytocoenological differences between Suaedetum communities in Hungary and Serbia (cf. Vučković 1986: 472). Furthermore, the names $S$. pannonica and $S$. prostrata in Hungary have been wrongly used with one replacing the other (ap. Fischer and Kästner 2011) which certainly had an impact on the treatment of communities.

The same records of Suaedetum pannonicae (Knežević \& Boža 1987) were cited later by other authors (Knežević \& Boža 1990, Knežević et al. 2002). Suaedetum pannonicae from Okanj without relevés were published by Knežević et al. (2009). In the species list they presented only $S$. pannonica. Later Panjković et al. (2011) reported both Suaeda species from Okanj.

Vegetation characteristics of the alliance Salicornion prostratae from Slano Kopovo and Rusanda were published by Knežević et al. (2002). The authors give detailed analysis of ecological preferences and floristical composition of four associations: "Salicornieto-Suaedetum maritimae continentale Knežević et Boža 88 and Suaedetum maritimae Soó 27 developing along the banks of Slano Kopovo, and stands of the associations Suaedetum maritimae Soó 27, Suaedetum pannonicae (Soó 27) Wendel. 43 and Salsoletum sodae Slavnić (39) 48 along the banks of Rusanda lake".

Our investigation of these localities shows a somewhat different vegetation pattern. Stands of Salicornia europaea s.l. were recorded only 2009 on a small area of the northern bank of Slano Kopovo. In 2012, this area was even reduced. We did not confirmed Salsola soda from any of these localities with the exception of a small patch with a few individuals in Melenci, $30 \mathrm{~m}$ from the bank of Mala Rusanda around the fences of the 
village cemetery in 2013. On the other hand, Suaeda prostrata was found on a small area on the southern bank of Mala Rusanda. Contrarily, we recorded large populations of Chenopodiaceae species with high nitrogen demand in the soil and higher tolerance to the human disturbance. This indicates higher amount of nutrients and soil eutrophication. This process is the most distinct in the area of Okanj, where these Chenopodiaceae are dominant. Also, only here we were able to confirm larger patches of Crypsis schoenoides, which indicates lower salinization (Eliáš et al. 2008). Plant communities on the majority of this localities belong to the class Crypsidetea aculeatae. S. pannonica can be found scattered in this class, (except Heleochloetum schoenoidis) in the stands relative to the association Atriplici prostratae-Chenopodietum crassifolii. Species combination Suaeda pannonica - Chenopodium chenopodioides, which was confirmed in Medura and Mala Rusanda on dried lake bottom (Cluster 3), is not known from the literature of the studied area. This type of vegetation was studied in the Hungarian Bácska region (Lake Sós-tó, Bácsalmás town), on the banks of Büdös-szék in the Kiskunság National Park (Dítě, Eliáš jun., Melečková, ined.). Further studies may show whether this is an individual association based on two dominants from two different classes like the association Crypsido-Suaedetum maritimae. In addition, S. pannonica often creates transition (in case of the northern bank of Rusanda lake) into the association of Puccinellietum limosae (class Festuco-Puccinellietea) likewise for instance in the Kiskunság region, lakes of Kelemén-szék and Büdös-szék (Dítě, Eliáš jun. \& Melečková, ined.).

It is also necessary to clarify the distribution and vegetation preferences of Suaeda prostrata. This even more intricate representative of the Suaeda genus in Serbia was during this study recorded only in a single case, therefore it is considered less frequent than S. pannonica.

\section{CONCLUSIONS}

Suaeda pannonica, a critically endangered species in Serbia known from about 10 localities in total were confirmed on four salt lakes in Banat and Bačka region (Medura, Slano Kopovo, Rusanda and Okanj). This situation indicates gradual vegetation changes and habitat loss at all remaining localities of S. pannonica in Serbia. According to our analysis of phytosociological relevés, besides Suaedetum pannonicae the species occurs also in associations within the class Thero-Suaedetea, alliance Salicornion prostratae: Salicornietum prostratae, Crypsido-Suaedetum maritimae and in a separate cluster, combination of species Suaeda pannonica - Chenopodium chenopodioides. The last vegetation type as 
well as the distribution and vegetation of Suaeda prostrata need further study.

\section{Acknowledgements}

The research was funded by the grant project of the Slovak Ministry of Education VEGA 2/0003/09. We wish to thank Ms Milica Rat from the Herbarium of the Faculty of Sciences, University of Novi Sad (BUNS) for the help with the completion of distribution data. We are indebted also to $\mathrm{PhD}$ Marjan Niketić for his useful and concise comments and suggestions.

\section{REFERENCES}

Akhani, H., Trimborn, P., Ziegler, H. (1997): Photosynthetic pathways in Chenopodiaceae from Africa, Asia and Europe with their ecological, phytogeographical and taxonomical importance. - Plant Systematics and Evolution 206: 187-221.

Barkmann, J.J., Doing, H., Segal, S. (1964): Kritische Bemerkungen und Vorschläge zur quantitativen Vegetationsanalyse. - Acta Botanica Neerlandica 13: 394-419.

Bassett, I.J., Crompton, C.W. (1978): The genus Suaeda (Chenopodiaceae) in Canada. - Canadian Journal of Botany 56(6): 581-591.

Borhidi, A. (2003): Magyarország növénytársulásai. - Akadémiai Kiadó, Budapest.

Boros, Á. (1959): A Mezőföld növény földrajza. In: Ádám, L. Marosi, S., Szilárd, J. (ed.): A Mezőföld Természeti Földrajza: 365-383. - Akadémiai Kiadó, Budapest.

Boža, P. (1999): Suaeda pannonica (G. Beck) Ascherson \& Graebner. In: Crvena knjiga flore Srbije 1, iščezli i krajnje ugroženi taksoni. 1: 312-314. Ministarstvo za životnu sredinu republike Srbije, Biološki fakultet Univerziteta u Beogradu, Zavod za zaštitu prirode republike Srbije, Beograd.

Boža, P., Vasić, O. (1986): Suaeda maritima (L.) Dum. subsp. prostrata (Pall.) Soó ex Soó. In: M. Sarić (ed.): Flora SR Srbije X, Dodatak (2): 55. - Srpska akademija nauka i umetnosti, odeljenje prirodno-matematičkih nauka, Beograd.

Boža, P., Knežević, A. (1988): O vrstama rodova Suaeda Forsk. 1775 i Oenothera L. 1753 u Vojvodini. - Unija bioloških naučnih društava Jugoslavije, serija G, Biosistematika 14(1): 17-22.

Budak, V. (1998): Flora i biljnogeografske odlike slatina Bačke. - Matica srpska, Novi Sad.

Butorac, B. (1993a): Biodiverzitet Vojvodine - Flora i vegetacija. In: Anonymous (ed.): Materijal za elaborat „Stručna osnova za politiku očuvanja biodiverziteta SR Jugoslavije. - Zavod za zaštitu prirode Srbije, radna jedinica Novi Sad. (manuscr.)

Butorac, B. (1993b): Vegetacija. In: Butorac, B. (ed.): Predlog za zaštitu prirodnog dobra „Selevenjske pustare“ kao specijalnog rezervata prirode: 9-15. - Zavod za zaštitu prirode Srbije, odeljenje u Novom Sadu. 
Butorac, B. (1999): Vegetacija. In: Pavkov, G. (ed.): Specijalni rezervat prirode „Slano Kopovo“, predlog za stavljanje pod zaštitu kao prirodnog dobra od izuzetnog značaja: 13-17. - Zavod za zaštitu prirode Srbije, radna jedinica Novi Sad.

Ciobanu, M., van Dobben, H. F., Popovici, I. (2004): Patterns of relationships between nematode communities and vegetation from some salt-affected areas in Transylvania (Romania). - Nematologia Mediterranea 32: 137-146.

Đakić, S.Ž., Knežević, S.A., Boža P.P. (2012): Some extinct plant taxa on the territory of Novi Sad and their vulnerability status in Vojvodina and Serbia. Zbornik Matice Srpske, serija prirodnih nauka 122: 45-61.

Dítě, D., Melečková, Z., Perić, R., Eliáš jun., P. (2013): The confirmed occurrence of Cyperus pannonicus in Vojvodina (northern Serbia). - Bulletin of the Natural History Museum, Beograd 6: 43-54.

Eliáš jun. P., Dítě D., Grulich V., Sádovský M. (2008): Distribution and communities of Crypsis aculeata and Heleochloa schoenoides in Slovakia. - Hacquetia, Ljubljana 7(1): 5-20.

Fischer, M.A., Kästner, A. (2011): Confusion about the correct identity of two Austrian Suaeda species (Chenopodiaceae) - both remarkable and "wellknown" halophytes. - Neilreichia 6: 165-182. [in German with English abstract]

Freitag, H., Lomonosova, M. (1996): Typification and identity of Suaeda crassifolia, S. prostrata and S. salsa, three often confused species of Suaeda sect. Brezia (Chenopodiaceae, Suaedoideae). - Willdenowia 36: 21-36.

Freitag, H., Walter, J., Wucherer, W. (1996): Die Gattung Suaeda (Chenopodiaceae) in Österreich, mit einem Ausblick auf die pannonischen Nachbarländer. Ann. Naturhist. Mus. Wien. 98N Suppl., S: 343-367.

Gajić, M. (1986): Fam. Chenopodiaceae. In: Gajić, M. (ed.): Flora i vegetacija Subotičko-Horgoške peščare: 96-100. - Šumarski fakultet, Beograd i Šumsko gazdinstvo, Subotica.

Godicl, Lj. (1980a): Stepska flora v severozahodni Jugoslaviji. - Slovenska akademija znanosti in umetnosti, Razred za naravoslovne vede, Razprave 22: 281-367.

Godicl, Lj. (1980b): Pannonische Endemiten am südlichen Rand der Pannonischen Ebene und im Neusiedlersee-Gebiet. - Biologisches Forschungsinstitut für Burgenland-Bericht 37: 73-82.

Gombocz, E. (1945): Diaria itinerum Pauli Kitaibelii I-II. - Természettudományi Múzeum Kiadványa, Budapest.

Guelmino, J. (1968): Zenta és környékének növényei. I. Virágosok. In: Građa za monografiju Sente 12. - Univerzitet u Novom Sadu.

Hennekens, S.M., Schaminée, J.H.J. (2001): TURBOVEG, a comprehensive database management system for vegetation data. - Journal of Vegetation Science 12: 589-591.

Jalas, J., Suominen, J. (1980): Atlas Florae Europaeae . Chenopodiaceae to Basellaceae. 5. - Committee for Mapping the Flora of Europe, Societas Biologica Fennica, Vanamo.

Kanitz, A. (1863): Reliquiae Kitaibelianae e manuscriptis musei nationalis hungarici. - Apud Guil. Braumüller, Vindobonae. 
Kapralov, M.V., Akhani, H., Voznesenskaya, E.V., Edwards, G., Franceschi, V., Roalson, E.H. (2006): Phylogenetic relationships in the Salicornioideae / Suaedoideae / Salsoloideae s.l. (Chenopodiaceae) clade and a clarification of the phylogenetic position of Bienertia and Alexandra using multiple DNA sequence datasets. - Systematic Botany 31(3): 571-585.

Király, G. (2009): Chenopodiaceae. In: Király, G. (ed.): Új Magyar Új magyar füvészkönyv: 118-127. - Aggteleki Nemzeti Park Igazgatósága, Jósvafö.

Knežević, A., Boža, P. (1987): Cenološka pripadnost vrsta Suaeda maritima (L.) Dum. i Suaeda pannonica Beck na lokalitetu kod Melenaca (Vojvodina) Banat. - Zbornik Matice Srpske, serija prirodnih nauka 72: 153-163.

Knežević, A., Boža, P. (1988): Horološki, sinekološki i cenološki aspekt ekspanzije karakterističnih vrsta zajednica sveze Thero-Salicornion Br.-Bl. (30) 1933. Pign. 1953. u srednjem Banatu. - Zbornik Matice Srpske, serija prirodnih nauka 74: 123-134.

Knežević, A., Boža, P. (1990): Asocijacijski kompleks halofitske vegetacije na priobalju akvatorije Rusande kod Melenaca (Banat). - Univerzitet u Novom Sadu, zbornik radova Prirodno-matematičkog fakulteta, serija za biologiju 20: 73-77.

Knežević, S.A., Boža, P.P., Milošev, S.D., Anačkov, T.G. (2002): Phytogeographical and ecological characteristics of the vegetation alliance TheroSalicornion Br.-Bl. 33 em. Tx. 50 growing on continental salt-affected soils (Banat, Yugoslavia). - Zbornik Matice Srpske, serija prirodnih nauka 102: 35-44.

Knežević, A., Boža, P., Stojanović, S., Milošev, D., Nikolić, Lj., Lazić, D., Stojšić, V. (2003): Specifičnosti i ugroženost biljnog pokrivača zaslanjenih staništa priobalja akvatorije Rusande. In: Monografija, Eko-konferencija 2003, Zaštita životne sredine gradova i prigradskih naselja: 289-294. - Ekološki pokret grada Novog Sada, Novi Sad.

Knežević, A., Boža, P., Stankov, M., Nikolić, L.J., Stojanović, S., Digurski D., Ljevanić, B., Polić, D. (2009): Plant cover of the saline grassland in the riparian zone of the Okanj oxbow lake (The Vojvodina province, Serbia). Annals of the Faculty of Engineering Hunedoara - Journal of Engineering VII/ 4: 189-194.

Lampinen, R. (2001): Universal Transverse Mercator (UTM) AND Military Grid Reference System (MGRS). [Downloadable from http://www.fmnh.helsinki.fi/ english/botany/afe/map/utm.htm]

Lomonosova, M.N., Krasnikova, S.A., Krasnikov, A.A., Sukhorukov, A.P., Bananova, V.A., Pavlova, N.S. (2005): Chromosome numbers of Chenopodiaceae species from Russia and Kazakhstan. - Botanical Journal 7: 34-39.

Marhold, K., Hindák, F. (1998): Zoznam nižších a vyšších rastlín Slovenska Checklist of non-vascular and vascular plants of Slovakia. - Veda, VSAV, Bratislava.

McNeill, J., Barrie, F.R., Buck, W.R., Demoulin, V., Greuter, W., Hawksworth, D.1., Herendeen, P.S., knapp, S., Marhold, K., Prado, J., Prud'homme van Reine, W.F., Smith, G.F., Wiersema, J.H., Turland, N. J. (2012): International Code of Nomenclature for algae, fungi, and plants (Melbourne Code). Regnum Vegetabile 154: 1-240. 
Mile, O., Walter, J. (2003): A Suaeda Forskål ex Scop. (Chenopodiaceae) nemzetség Magyarországon. - Flora Pannonica 1(1): 29-43.

Molnár, Zs., Borhidi, A. (2003): Hungarian alkali vegetation: Origins, landscape history, syntaxonomy, conservation. - Phytocoenologia (Stuttgart) 33: 377 - 408.

Mucina, L. (1993): Puccinellio-Salicornietea. In: Mucina L., Grabherr G., Ellmauer T. (ed.): Die Pflanzengesellschaften Österreichs, Teil 1, Anthropogene Vegetation: 522-549. - Fischer, Stuttgart \& New York.

Nikolić, T. (2005): Suaeda vera J. F. Gmelin. In: Nikolić, T., Topić, J. (eds): Crvena knjiga vaskularne flore Hrvatske: 525-526. - Ministarstvo kulture, Državni zavod za zaštitu prirode, Republika Hrvatska.

Obradović, M. (1966): Biljnogeografska analiza flore Fruške gore. - Matica srpska, Novi Sad.

Obradović, M. (1987): O nekim odlikama endemske flore Vojvodine. In: Vuković, T. (ed.): Naučni skup: Zaštita endema u živom svijetu Jugoslavije, Sarajevo, 15. i 16. maja 1986, posebna izdanja. knjiga LXXXIII (14): 103-112. Akademija nauka i umjetnosti Bosne i Hercegovine, Odjeljenje prirodnih i matematičkih nauka, Sarajevo.

Obradović, M., Budak, V. (1974): Neke biljnogeografske karakteristike slatina okoline Novog Sada. - Zbornik Matice Srpske, serija prirodnih nauka 46: 14-32.

Obradović, M., Boža, P. (1986): Prodromus flore papratnica i semenica Subotičke peščare i bliže okoline. - Univerzitet u Novom Sadu, zbornik radova Prirodnomatematičkog fakulteta, serija za biologiju 16: 121-141.

Panjković, B., Perić, R., Stojšić, V. (2011): Okanj bara-important center of floristic and ecosystem diversity of the Tisa river basin (Serbia). - Studia Universitatis "Vasile Goldiş" (Arad), Seria Ştiinţele Viętii 21(4): 767-772.

Parabućski, S., Stojanović, S., Butorac, B., Pekanović, V. (1986): Prodromus vegetacije Vojvodine. - Zbornik Matice srpske za prirodne nauke 71: 5-40.

Prodán, Gy. (1914): Bács-Bodrog vármegye sziki növényei. - Magyar Botanikai Lapok 13(1/5): 96-138.

Prodán, Gy. (1915): Bács-Bodrog vármegye flórája. - Magyar Botanikai Lapok 14(5/12): 120-269.

Schlosser, J.C.K., Vukotinović, L.F. (1869): Flora Croatica. - Fr. Župan (Albrecht \& Fiedler), Zagrabiae.

Schmidt, D. (2007): Alkali vegetation fragments in the surroundings of Győr (NW Hungary). - Flora Pannonica 5: 95-104.

Slavnić, Ž. (1939): Pregled najvažnijih flornih elemenata zaslanjenih tala Jugoslavije. - Arhiv Ministarstva poljoprivrede (Beograd) 6(15): 77-91.

Slavnić, Ž. (1943): Adatok az alsó Tiszavidék flórájának ismeretéhez. - Botanikai közlemények 11(5-6): 400-405.

Slavnić, Ž. (1948): Slatinska vegetacija Vojvodine. - Arhiv za poljoprivredne nauke i tehniku (Beograd) 3(4): 76-142.

Slavnić, Ž. (1953): Biljnogeografska analiza i florogeneza sremske halofitske vegetacije. - Zbornik Matice Srpske, serija prirodnih nauka 4: 35-64. 
Slavnić, Ž. (1972): Fam. Chenopodiaceae Less. In: Josifović, N. (ed.): Flora SR Srbije III: 10-51. - Srpska akademija nauka i umetnosti, odeljenje prirodnomatematičkih nauka, Beograd.

Sturc, B. (1973): Mit kell megtartanunk és megvédenunk Bácska északkeleti részének növénytakarójában. - Létünk (Szabadka) 4: 119-133.

Šumberová, K. (2007): Vegetation of annual succulent halophytes (TheroSalicornietea strictae). In: Chytrý, M. (ed.): Vegetace ČR 1: 143-149. Academia, Praha.

Tatár, M. (1939): A pannóniai flóra endemikus fajai. - Debrecen.

Thiers, B. (2014): Index Herbariorum: A global directory of public herbaria and associated staff. - New York Botanical Garden's Virtual Herbarium. http://sweetgum.nybg.org/ih/

Tichý, L. (2002): JUICE, software for vegetation classification. - Journal of Vegetation Science 13: 451-453.

Trinajstić, I. (1980): Rod Suaeda Forskål ex Scop. In: Trinajstić, I. (ed.): Analitička flora Jugoslavije 1(6): 829-831. - Grafički zavod Hrvatske, Zagreb.

Tutin, T.G., Heywood, V.H., Burges, N.A., Moore, D.M., Valentine, D.H., Walters, S.M., Webb, D.A. (1968): Flora Europaea 2. - University Press, Cambridge.

Tutin, T.G., Heywood, V.H., Burges, N.A., Moore, D.M., Valentine, D.H., Walters, S.M., Webb, D.A. (1972): Flora Europaea 3. - University Press, Cambridge.

Tutin, T.G., Heywood, V.H., Burges, N.A., Moore, D.M., Valentine, D.H., Walters, S.M., Webb, D.A. (1976): Flora Europaea 4. - University Press, Cambridge.

Tutin, T.G., Heywood, V.H., Burges, N.A., Moore, D.M., Valentine, D.H., Walters, S.M., Webb, D.A. (1980): Flora Europaea 5. - University Press, Cambridge.

Tutin, T.G., Burges, N.A., Chater, A.O., Edmondson J.R., Heywood, V.H., Moore, D.M., Valentine, D.H., Walters, S.M., Webb, D.A. (1993): Flora Europaea ed. 2, 1. - University Press, Cambridge.

Uotila, P. (2011): Chenopodiaceae (pro parte majore). In: Euro+Med Plantbase the information resource for Euro-Mediterranean Diversity.

Vučković, R. (1986): Asocijacijski kompleks halofitske vegetacije na lokalitetu Deračka bara u srednjem Banatu. In: Mihaljev, I. (ed.): Zbornik radova sa naučnog skupa „Čovek i biljka“, Novi Sad, 21-22. septembra 1983: 469-478. Matica srpska, Novi Sad.

Weber, H.E., Moravec, J., Theurillat, J.-P. (2000): International Code of Phytosociological Nomenclature, ed. 3. - Journal of Vegetation Science 71: 739-768.

Wendelberger, G. (1943): Die Salzpflanzengesellschaften des Neusiedler Sees. Wiener botanische Zeitschrift 92 (3): 124-144.

Wendelberger, G. (1950): Zur Soziologie der kontinentalen Halophytenvegetation Mitteleuropas. - Abh. Akad. Wiss. Wien, Math.-Nat. K1. (Wien) 108: 1-180 + Tab. 
Zhu Gelin, Mosyakin, S.L., Clemants, S. E. (2003): Chenopodiaceae. In: Wu Zhengyi, Raven P. H. (ed.): Flora of China 5: 35-414. - Beijing: Science Press $\&$ St. Louis: Missouri Botanical Garden Press.

Zrnić, D. (1993): Izmene u flori Slanog jezera pod uticajem prirodnih i antropogenih faktora. - Rad vojvođanskih muzeja 35: 253-266.

\section{APPENDIX}

\section{Historical and recent distribution of $S$. pannonica in Serbia}

Bačka: CS90 Subotica (Godicl 1980a: 79); DS00 Palić Lake? ["Palicsi-tó", subnom. S. maritima L. and (L.) Dum.] (Prodán 1914: 115?; "in some cases is very similar to S. pannonica G. Beck"; Prodán 1915: 216?); Krvavo Lake ("very similar to S. pannonica Beck, but not typical" Slavnić 1972: 49?; Godicl 1980b: 63); Slano Lake [“Sóstó”] (Sturc 1973: 126; Gajić, 1986: 100; Zrnić 1993: 261); CR48 Sombor: Gakovo? ["Gádor", subnom. S. maritima L. and (L.) Dum.] (Prodán 1914: 115?; "in some cases is very similar to S. pannonica G. Beck" 1915: 216?; “near Sombor” Đakić 2012: 47-48); CR59 Riđica, Medura Lake (Dítě et al. 2013: 47); CR58 Stanišić? [“Örszállás”, subnom. S. maritima L. and (L.) Dum.] (Prodán 1914: 115?; "in some cases is very similar to $S$. pannonica G. Beck" 1915: 216?; "near Sombor" Đakić 2012: 47-48); DR28 Senta (Godicl 1980b: 63); Gornji Breg (Slavnić 1939: 79); DR01 Novi Sad (Obradović \& Budak 1974: 19; Godicl 1980a: 79; Obradović 1987: 107).

Banat: DR35 Novi Bečej (subnom. S. maritima (L.) Dum., Kovačev, G., [s.d.], BUNS; Lindtner, V. 18-Jun-1955, BEO; Boža 1999: 313); at the bottom of a dried puddle (subnom. S. maritima (L.) Dum., Andrejević, N. [s.d.], BUNS); Slano Kopovo (Kovačev, G. 03-Aug-1976, BUNS; Boža, P. Sep-1987, BUNS; Stojšić, V. 19-Jul-1990, PZZP; Butorac, B., Knežević, A. 03-Aug-1990, PZZP; Butorac, B. 22Aug-1997, PZZP; Stojšić, V. 03-Aug-1990, PZZP; Boža, P., Stevanović, V. 10Aug-1998, BEOU; Perić, R. 13-Aug-2009, PZZP; Butorac 1993a: 24; Boža 1999: 313; Knežević, A., Butorac, B., Stojšić, V. 1990 Butorac 1999: 15, 17), succulent halophytes vegetation, ass. Suaedetum pannonicae (Butorac, B. 03-Aug-1990, PZZP); saltmarsh (Kovačev, G. 03-Aug-1976, BUNS); DR44 Zrenjanin: Melenci (Boža, P. 13-Sep-1984, BUNS); Rusanda Lake, ass. Suaedetum pannonicae (Soó 1927) Wendelberger 1943, ass. Salsoletum sodae Slavnić 1939 (Knežević \& Boža 1987: 158; Boža \& Knežević 1988: 17-18; Knežević \& Boža 1988: 130, 132; 1990: 73-76; Butorac 1993a: 24; Tucakov, J. 1966, BEO; Boža, P., Stevanović, V. 10-Aug-1998, BEOU; Boža 1999: 313; Knežević et al. 2002: 38; Knežević et al. 2003: 293), Rusanda spa, saltmarsh (Boža, P. 04-Sep-1971, BUNS); DR43 Elemir: Okanj, dried lake and lakeshore (Stankov, M. 20-Jul-2002; 17-Aug-2002; 14-Sep-2002; 14-Aug-2003; 05-Sep-2003; BUNS); Okanj bara, on north end of the lake, $\approx \mathrm{N} 45^{\circ} 29^{\prime}$ 09.42", E 20 18' 10.68", 71 m (Perić, R. 13-Aug-2009, PZZP; Knežević et al. 2009: 191; Panjković et al. 2011: 769-770).

General data: Vojvodina (Trinajstić 1980: 831); Bačka (Slavnić 1953: 52; Obradović 1987: 107; Budak 1998: 142); Banat (Anonymous 1989, BUNS; Slavnić 1953: 52; Obradović 1987: 107); Subotica Sand (Obradović \& Boža 1986: 136). 


\section{Incorrectly cited data:}

(referring to $S$. prostrata): Subotica, Horgoš, Senta (Slavnić 1943, ap. Sturc 1973: 126); Kelebija (Boža, P. 15-Aug-1968, BUNS; M. Obradović pers. comm. Budak 1998: 142); Selevenjske pustare: Kilapoš (Butorac 1993b: 13; 1993c: 18, ap. Boža 1999: 313); Zrenjanin: Melenci (Rusanda Lake) (Butorac, B., Knežević, A. 03-Aug-1990, PZZP; Boža 1999: 313).

(referring to Bassia prostrata): Obradović 1966: 134, 1987: 107.

\section{РАСПРОСТРАњЕЊЕ И ЗАЈЕДНИЦЕ SUAEDA PANNONICA У СРБИЈИ}

ДАНИЕЛ ДИТЕ, РАНКО ПЕРИЋ, ПАВОЛ ЕЛИАШ МЛ., ЗУЗАНА МЕЛЕЧКОВА

\section{Р Е 3 И М Е}

У раду су дати подаци о распрострањењу и фитоценозама врсте Suaeda pannonica у Србији. Између 2009. и 2013. године потврђено је присуство $S$. pannonica на четири посећена локалитета од укупно око десет њених познатих налазишта. Пронађена је на обалама и дну сланих језера Медура, Слано Копово, Русанда и Окањ у Бачкој и Банату. Такође је дато и 25 фитоценолошких снимака у којима је едификатор S. pannonica. Поред заједнице Suaedetum pannonicae, ова врста се такође јавља у заједницама из класе Thero-Suaedetea, свезе Salicornion prostratae: Salicornietum prostratae, Crypsido-Suaedetum maritimae и у посебној групи, односно комбинацији врста Suaeda pannonica Chenopodium chenopodioides, која као синтаксономска јединица захтева даље проучавање. Поређење са подацима објављеним у прошлости указује на постепене промене вегетације и губитак станишта на свим преосталим налазиштима $S$. pannonica у Србији. 